\title{
The Involvement of Purinergic System in Pain: Adenosine Receptors and Inosine as Pharmacological Tools in Future Treatments
}

\author{
Francisney Pinto Nascimento ${ }^{1,2}$, \\ Sérgio José Macedo Jr. ${ }^{2}$ and Adair Roberto Soares Santos ${ }^{1,2}$ \\ ${ }^{1}$ Department of Pharmacology; \\ ${ }^{2}$ Laboratory of Neurobiology of Pain and Inflammation, \\ Department of Physiological Sciences; Universidade Federal de Santa Catarina
}

Brazil

\section{Introduction}

During the recent years, the interest in the purinergic system has been gaining importance, and this interest is not accidental. The purinergic system is so far known to be involved in several physiological conditions in mammals, becoming a potential therapeutic target for the treatment of many pathologies and disorders. One of the physiological roles is the control of pain. This chapter will emphasize adenosine receptors (P1) and its activation and inhibition by adenosine and by specific agonists or antagonists in the treatment of pain. Although most of the studies quoted in this chapter were performed in animals, in this chapter we will use the expression analgesia instead of antinociception (term used to report pain in animals) to simplify our communication. Some drugs that act on adenosine receptors have presented interesting results in clinical studies of pain and other drugs are under investigation. Of note, it has recently been shown that inosine, a metabolite of adenosine, has significant analgesic effects in several pre-clinical models of pain. Thus, the inosine can be an important tool in this area of study or even a molecule of interest for future pharmacological approaches, knowing that such as adenosine, it is produced endogenously and devoid of side effects in normal doses. In addition, new approaches using enzyme inhibitors of the purinergic system or supplies of adenosine suggest alternatives to potentiate and lasting analgesic effects of adenosine or analogs. Moreover, the release of purines and the adenosine $\mathrm{A}_{1}$ receptor activation are essential to analgesia by acupuncture in mice. Thus, purinergic system will be the target of many future pain-treatment researches. After all, it is indispensable to students and biomedical professionals to know and understand basic concepts about this endogenous system.

\section{Involvement of purinergic system in pain}

\subsection{Purinergic receptors: History and involvement in pain}

Purinergic receptors history began when Drury and Szent-Györgi described the potent actions of purines adenine and adenosine on the heart and blood vessels (Drury \& Szent- 
Györgi, 1929). Later, in 1970 Burnstock presented evidence that ATP acted as a neurotransmitter in nonadrenergic noncholinergic (NANC) nerves supplying the gut, and finally, in 1972, the purinergic neurotransmission hypothesis was proposed (Burnstock, 1972). With these discoveries, the number of publications involving ATP and its metabolites grew quickly and continues to do so (Figure 1).

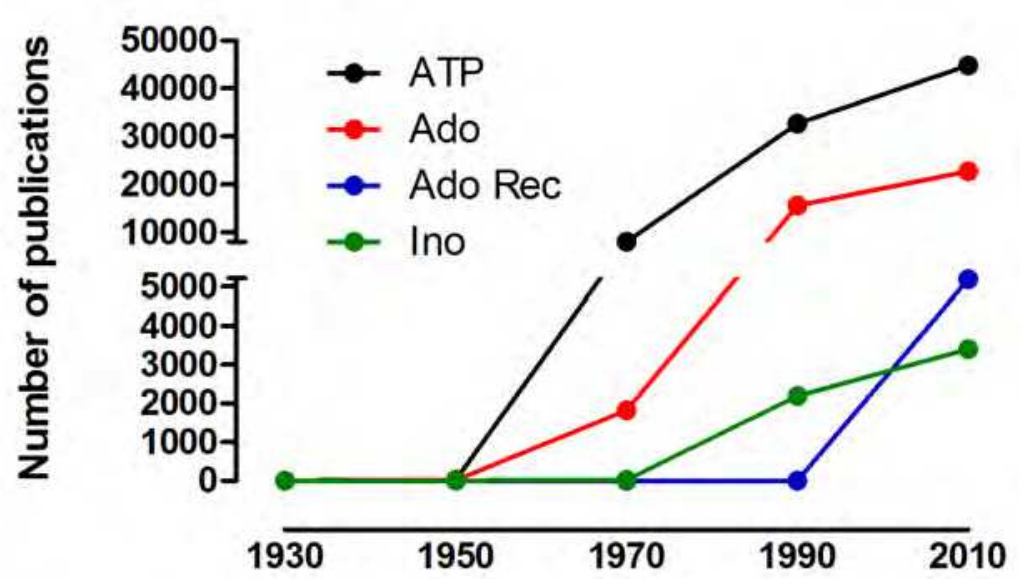

Fig. 1. Total of publications with keywords ATP, Adenosine (Ado), Adenosine Receptors (Ado Rec) and Inosine (Ino) from 1930 until 2010. Source: Pubmed

Afterwards, it was established that the ATP acted as a cotransmitter with classical transmitters in both the peripheral nervous system and in the central and that purines are also powerful extracellular messengers to non-neuronal cells (Burnstock \& Knight, 2004). Burnstock, in 1978, provided the basis for the distinction of two classes of purinergic receptors; adenosine-sensitive P1 and ATP-sensitive P2 receptor classes. In 1985, Burnstock and Kennedy proposed a basis for distinguishing two types of P2 purinoceptors, namely, P2X and P2Y. Afterwards, in 1994 Abbracchio and Burnstock through studies of transduction mechanisms and cloning of both P2X and P2Y receptors put forward a new nomenclature system, naming them, P2X ionotropic ligand-gated ion channel receptors and P2Y metabotropic $G$ protein-coupled receptors, respectively. Currently, seven subtypes of $\mathrm{P} 2 \mathrm{X}$ receptors $\left(\mathrm{P} 2 \mathrm{X}_{1}, \mathrm{P} 2 \mathrm{X}_{2}, \mathrm{P} 2 \mathrm{X}_{3}, \mathrm{P} 2 \mathrm{X}_{4}, \mathrm{P} 2 \mathrm{X}_{5}, \mathrm{P} 2 \mathrm{X}_{6}, \mathrm{P} 2 \mathrm{X}_{7}\right)$ and eight subtypes of $\mathrm{P} 2 \mathrm{Y}$ receptors $\left(\mathrm{P}_{1} \mathrm{Y}_{1}, \mathrm{P}_{2} \mathrm{Y}_{2}, \mathrm{P}_{2} \mathrm{Y}_{4}, \mathrm{P}_{2} \mathrm{Y}_{6}, \mathrm{P}_{2} \mathrm{Y}_{11}, \mathrm{P}_{2} \mathrm{Y}_{12}, \mathrm{P}_{2} \mathrm{Y}_{13}, \mathrm{P}_{2} \mathrm{Y}_{14}\right)$ are clearly established. P2X and P2Y receptor activation by ATP stimulates cellular excitability, augments the release of excitatory amino acids, and consequently initiates pain responses (Burnstock, 2007; Burnstock \& Williams, 2000). In the context of pain neurotransmission, preclinical studies show us that activation of P1 receptors by adenosine decreases pain, inflammation, and cellular excitability (McGaraughty \& Jarvis, 2006). During the 80's and 90's research evaluating purinergic system in pain rocketed (Figure 2). 


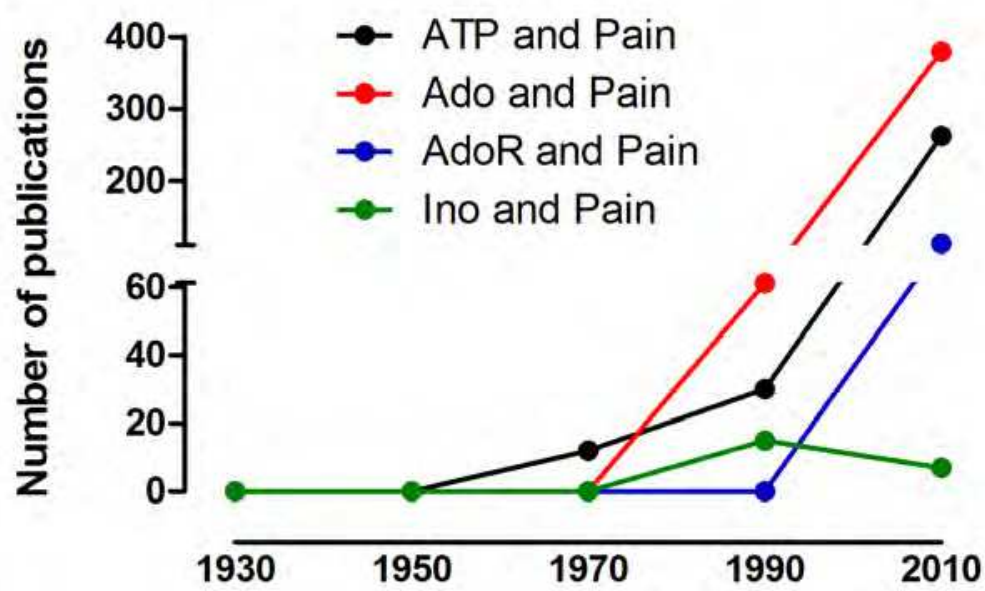

Fig. 2. Total of publications with keywords ATP, Adenosine (Ado), Adenosine Receptors (AdoR) and Inosine (Ino) plus Pain from 1930 until 2010. Source: Pubmed

\section{Adenosine receptors and pain}

\subsection{Adenosine receptors}

Adenosine is the natural ligand of P1 receptors, also called adenosine receptors. All these receptors are G-protein coupled and are divided according to pharmacological, biochemical and molecular properties into four subtypes: $A_{1}, A_{2 A}, A_{2 B}$ and $A_{3}$. Each receptor has a distinct distribution and due to its special features, has distinct roles as well (Burnstock et al., 2011; Fredholm et al., 2011; Ralevic \& Burnstock, 1998; Ribeiro et al., 2002; Sawynok \& $\mathrm{Liu}, 2003)$. Adenosine receptors were cloned and characterized in several mammal species (Burnstock, 2008).

\subsection{Distribution of adenosine receptors}

Adenosine receptors are present in several species and in distinct tissues. However, their distribution is quite irregular and different among species and mainly among tissues (Fredholm et al., 2011). $A_{1}$ receptor $\left(A_{1 R}\right)$ is a ubiquitous receptor. In the central nervous system, it is distributed in the cerebellum, cerebral cortex, hippocampus, thalamus, spinal cord (substantia gelatinosa), brain stem, olfactory bulb and other central sites. Peripherally $\mathrm{A}_{1 \mathrm{R}}$ distribution is less wide than centrally, but there is a considerable density of $A_{1 \mathrm{R}}$ in sensory afferent fibers, mainly on C-fibers which are responsible for receiving and conducting the painful stimuli (Dixon et al., 1996; Sawynok, 2009). A $A_{2 A}$ receptor $\left(A_{2 A R}\right)$ has an even distribution between central and peripheral nervous system, but mainly in central structures as nucleus accumbens, putamen, caudate and in immune tissues, vascular smooth muscle, endothelium, platelets and sensory neurons (Dixon et al., 1996; Fredholm, 1995; Ralevic \& Burnstock, 1998; Sawynok, 2009). $\mathrm{A}_{2 \mathrm{~B}}$ receptor $\left(\mathrm{A}_{2 \mathrm{BR}}\right)$ is also a ubiquitous receptor and it has been found either in many central or peripheral tissues. However, $A_{2 B R}$ density is 
very low and it has been found in great density only in bowel and bladder. $A_{3}$ receptors $\left(\mathrm{A}_{3 \mathrm{R}}\right)$ are widely distributed in several mammals, however, few studies have indicated specific roles for this receptor (Dixon et al., 1996; Ralevic \& Burnstock, 1998; Salvatore et al., 1993).

\subsection{General adenosine receptor signaling}

All adenosine receptors are coupled to G-protein. Nevertheless there are many kinds of Gprotein and each one may activate a distinct pathway. Thus, the four adenosine receptors can stimulate or inhibit several pathways and consequently exert many physiological actions (Jacobson \& Gao, 2006; Ralevic \& Burnstock, 1998). We show below the main signaling characteristics of each adenosine receptor.

\subsection{1 $\mathrm{A}_{1}$ receptor signaling}

$\mathrm{A}_{1 \mathrm{R}}$ is coupled to $\mathrm{Gi} / 0$ protein family which is pertussis toxin-sensitive. Most of the biological effects induced by $\mathrm{A}_{1 \mathrm{R}}$ activation are due to inhibition of cAMP second messenger (Burnstock, 2007; Jacobson \& Gao, 2006; Ralevic \& Burnstock, 1998; Sawynok, 1998) (Figure 3 and Table 1).

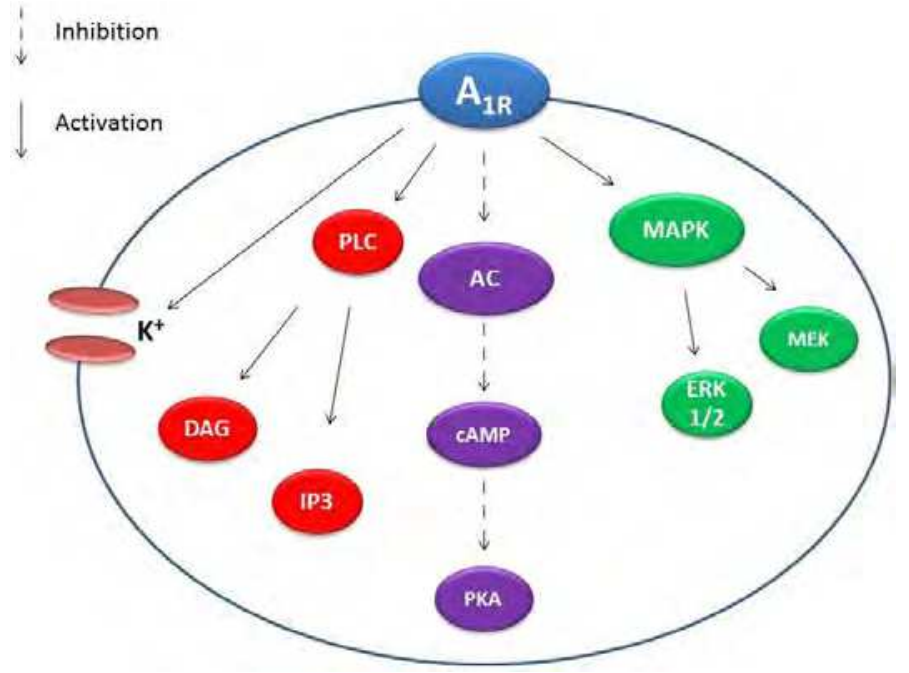

Fig. 3. Adenosine $A_{1}$ receptors and its main pathways. $A_{1 R}$, adenosine $A_{1}$ receptor; $A C$, adenylate cyclase; cAMP, cyclic adenosine monophosphate; DAG, diacylglicerol; ERK1/2, extracellular signal-regulated kinases 1 and 2; $\mathrm{IP}_{3}$, inositol triphosphate; $\mathrm{K}^{+}$, potassium channels; MAPK, mitogen-activated protein kinase; MEK, MAPK and ERK kinase; PKA, protein kinase; PLC, phospholipase C.

Beta and gamma subunities of $\mathrm{A}_{1 \mathrm{R}}$, when activated stimulate phospholipase $\mathrm{C}$ (PLC). Activation of PLC cleaves phosphatidylinositol 4,5-bisphosphate $\left(\mathrm{PIP}_{2}\right)$ into diacylglycerol (DAG) and inositol 1,4,5-trisphosphate $\left(\mathrm{IP}_{3}\right)$ leading to increased levels $\mathrm{Ca}^{+2}$. Moreover, the enhancement of intracellular calcium can induce some enzymes such as protein kinase $\mathrm{C}$ 
(PKC), phospholipase D (PLD), phospholipase $\mathrm{A}_{2}\left(\mathrm{PLA}_{2}\right)$ and others. Furthermore, adenosine or adenosine agonists can activate $\mathrm{K}^{+}$channels (Jacobson \& Gao, 2006; Megson et al., 1995; Ralevic \& Burnstock, 1998). A $A_{1 R}$ activation can also activate PI3K and MAPK pathways, more specifically ERK1/2 and MEK inducing gene expression changes and glial cell protection (Boison et al., 2010; Shulte \& Fredholm, 2003).

\subsection{2 $\mathrm{A}_{2 \mathrm{~A}}$ receptor signaling}

$A_{2 A R}$ is coupled to Gs (the most part) and Golf protein (mainly in striatum). The main intracellular event after activation of these proteins is adenylate cyclase activation followed by cAMP production enhancement (Table 1).

\begin{tabular}{|c|c|c|c|c|c|c|c|}
\hline Receptor & $\begin{array}{l}\text { Adenosine } \\
\text { affinity } \\
\text { (ECSO;nm) }\end{array}$ & G-protein & CAMP & PKA & PLC & $\begin{array}{c}\mathrm{Ca}^{2} \\
\text { channels }\end{array}$ & $\begin{array}{l}\mathrm{K}^{\mathrm{T}} \\
\text { channels }\end{array}$ \\
\hline$A_{1}$ & $\sim 70$ & Gi/Go & Decrease & Inhibits & Activates & Inhibits & Activates \\
\hline$A_{2 A}$ & $\sim 150$ & Gs/Golf & Increase & Activates & . & $\begin{array}{l}\text { Inhibits } \\
\text { or } \\
\text { Activates }\end{array}$ & Activates \\
\hline$A_{2 B}$ & $\sim 5100$ & Gs/Gq & Decrease & Activates & Activates & & \\
\hline$A_{3}$ & $\sim 6500$ & Gi/Go & Increase & Inhibits & Activates & & \\
\hline
\end{tabular}

Table 1. Adenosine receptors signaling. Adapted from Ralevic and Burnstock, 1998; Sawynok and Liu, 2003; Jacobson and Guao, 2006.

The increasing of cAMP stimulates cAMP-dependent kinase (PKA). Thus, PKA becomes able to activate several pathways through PKC, calcium channels, potassium channels, cAMP responsive element-binding (CREB), MAPK, PLC activation (Burnstock, 2007; Cunha et al., 2008; Fredholm et al., 2003, 2007; Jacobson \& Gao, 2006; Ralevic \& Burnstock, 1998).

\subsection{3 $A_{2 B}$ receptor signaling}

Through Gs and $\mathrm{Gq}$ activation $\mathrm{A}_{2 \mathrm{~B}}$ receptor induces adenylate cyclase and PLC. In humans, $\mathrm{A}_{2 \mathrm{BR}}$ can increase intracellular calcium by $\mathrm{IP}_{3}$ activation. Moreover, the arachidonic acid pathway is also involved in $\mathrm{A}_{2 \mathrm{BR}}$ signaling (Feoktistov \& Biaggioni, 2011; Jacobson \& Gao, 2006; Peakman and Hill, 1994).

\subsection{4 $A_{3}$ receptor signaling}

$A_{3 R}$ like $A_{1 R}$ is coupled to $\mathrm{Gi} / 0$ and also to $\mathrm{Gq} / 11$ protein. Its main signaling transduction is the inhibition of adenylate cyclase and stimulation of PLC, IP, DAG, PKC and PLD. Also, like other adenosine receptors, $\mathrm{A}_{3 \mathrm{R}}$ activates MAPK pathway, mainly ERK1/2 (Abbracchio et al., 1995; Armstrong \& Ganote, 1994; Palmer et al., 1995; Shneyvays et al., 2004). 


\section{$3.4 A_{1}$ receptors and pain}

$\mathrm{A}_{1 \mathrm{R}}$ is the main responsible for inducing analgesia among the adenosine receptors (Burnstock et al., 2011; Sawynok, 1998; Sawynok \& Liu, 2003). It has been shown that $A_{1 R}$ is widely distributed in the dorsal spinal cord, mainly in lamina II (substantia gelatinosa) (Choca et al., 1988; Horiuchi et al., 2010; Sawynok, 1998). In this site, many afferent sensory nerve have connections with post-synaptic neurons. Also, $A_{1 R}$ are localized in the descending projection within dorsal horn (Choca et al., 1988).

\subsubsection{Effects of $A_{1}$ receptor activation in acute pain}

There are several published data showing the important effect of $\mathrm{A}_{1 \mathrm{R}}$ in controlling acute pain (review see Jacobson \& Gao, 2006; Sawynok, 1998). Moreover, it has been shown that systemic administration of various $\mathrm{A}_{1 \mathrm{R}}$ agonists can produce analgesic effect in several models of acute pain in animals (Gong et al., 2010; Sawynok, 1998). Probably, these effects are caused by peripheral, supraspinal and mostly by spinal $A_{1 R}$. In mice lacking $A_{1 R}$ (knockout animals) a lower pain threshold was observed in hyperalgesia tests (Wu et al., 2005). Further, analgesic effect induced by intrathecal adenosine was abolished as well as the increase of thermal hyperalgesia in $A_{1 R}$ knockout mice (Johansson et al., 2001).

Several studies published show that intrathecal injection of $\mathrm{A}_{1 \mathrm{R}}$ agonists cause analgesia in various animal models of acute pain, including tail flick, tail immersion, hot-plate, formalin, acetic acid, capsaicin models and others (Nascimento et al., 2010; Song et al., 2011; Zahn et al., 2007).

$\mathrm{A}_{1 \mathrm{R}}$ is also found in primary afferent neurons and in the cell body and the dorsal root ganglia (Lima et al., 2010; Sawynok, 2009), then it has an important role in modulation of peripheral pain. Many studies have shown that administration of $A_{1 R}$ agonists into the paw of animals causes an analgesic effect in several animal models of pain. It has been shown that $\mathrm{A}_{1 \mathrm{R}}$ activation in the periphery inhibits formalin-induced pain and reduces hyperalgesia induced by $\mathrm{PGE}_{2}$ (Karlsten et al., 1992; Taiwo \& Levine, 1990). Further, when the peripheral adenosine $A_{1 R}$ is activated, it triggers the $\mathrm{NO} / \mathrm{cGMP} / \mathrm{PKG} / \mathrm{K}_{\mathrm{ATP}}$ intracellular signaling pathway and then inhibits pain (Lima et al., 2010). Moreover, $\mathrm{A}_{1 \mathrm{R}}$ agonists reduce the thermal hyperalgesia, but not mechanical allodynia, caused by sciatic nerve injury. The thermal hyperalgesia is mediated by $C$ fibers and mechanical allodynia, in turn, is mediated by A fibers, which demonstrates the presence of $A_{1 R}$ in $C$ but not in A fibers (Sawynok, 2009).

\subsection{2 $\mathrm{A}_{1}$ receptor and chronic pain}

Several authors have shown that different agonists of $A_{1 R}$ are able to reduce distinct kinds of chronic pain. The agonist R-PIA inhibits mechanical allodynia induced by spinal nerve ligation in rats (Hwang et al., 2005; Song et al., 2011). In addition, R-PIA also reduces thermal pain threshold in rats that underwent an injury in the spinal cord (Horiuchi et al., 2010). Moreover, other mechanisms are generally involved in analgesic effect in chronic pain induced by $A_{1 R}$ activation, such as inhibition of glutamate release. Another $A_{1 R}$ agonist, $\mathrm{CPA}$, when given to rats, inhibits pain induced by arthritis and pain induced by neuropathy (Curros-Criado \& Herrero, 2005). Also, in experiments with $\mathrm{A}_{1 \mathrm{R}}$ knockout mice it has been observed that these animals present a lower pain threshold than wild-type animals in inflammatory and neuropathic pain models (Wu et al., 2005). 


\subsubsection{Interactions between $A_{1}$ receptor and opioid system}

There is a strong relationship between opioidergic and adenosinergic systems in pain modulation. Morphine and other opioids are able to release adenosine (Sawynok et al., 1989; Sweeney et al., 1987a,b; Sweeney et al., 1989). Adenosine or analog administration combined with opioids enhances the analgesic effect of the latter (DeLander \& Hopkins, 1986). However, administration of methylxanthines, adenosine receptor antagonists, can augment, decrease or have no effect on analgesic activity of opioids (Sawynok, 2011). In addition, $\mathrm{A}_{1 \mathrm{R}}$ can undergo dimerization with $\mu$ receptor in afferents neurons and induce the decrease of cAMP production (Sawynok, 1998).

\subsubsection{Interactions among $A_{1}$ receptor and other receptors in pain mechanisms}

$A_{1 R}$ is able to dimerize with alpha-2-adrenergic receptor. Also, it has been shown that serotonin releases adenosine from primary afferents and that $\mathrm{A}_{1 \mathrm{R}}$ receptor antagonist blocks serotonin analgesic actions, suggesting a close involvement between adenosinergic and serotoninergic systems in pain modulation (Sawynok, 1998).

\subsection{5 $\mathrm{A}_{1}$ agonists/antagonists}

Methylxanthines (caffeine included) are natural antagonists of adenosine $A_{1 R}$ and $A_{2 A R}$. However, the main selective agonists/antagonists to $A_{1 R}$ are synthetics. Some of them are listed in Table 2.

\begin{tabular}{|l|l|l|}
\hline Role of drugs & Drug & \multicolumn{1}{c|}{ Chemical name } \\
\hline R-PIA & (-)-N6-(2-Phenylisopropyl)adenosine \\
Agonists $\mathrm{A}_{1 R}$ & CHA & N6-ciclohexyladenosine \\
& CPA & N6-Cyclopentyladenosine \\
& CCPA & 2-chloro-N6-cyclopentyladenosine \\
& CPT & 8-cyclopentyl-1,3-dimethylxanthine \\
Antagonists $A_{1 R}$ & DPCPX & 8-Cyclopentyl-1,3-dipropylxanthine \\
& 8-PT & 8-phenyltheophylline \\
\hline
\end{tabular}

Table 2. Principal adenosine $\mathrm{A}_{1}$ receptor agonists and antagonists.

\section{$3.5 \mathrm{~A}_{2 \mathrm{~A}}$ receptors and pain}

Taiwo \& Levine (1990) demonstrated clear distinct effects of $A_{1 R}$ and $A_{2 A R}$ activation in peripheral pain. They showed that, in peripheral sites, $A_{1 R}$ mediates analgesia while $A_{2 A R}$ facilitates painful perception. In addition, other studies also showed that peripheral $A_{2 A R}$ activation induced pain (Doak \& Sawynok, 1995; Li et al., 2010; Taiwo \& Levine, 1990). However, systemically and spinally, the role of $\mathrm{A}_{2 \mathrm{AR}}$ is not entirely clear. Some publications have demonstrated that $A_{2 A R}$ activation induces pain (Bastia et al., 2002; Hussey et al., 2007). On the other hand, other authors have showed a reduction of pain when $A_{2 A R}$ is activated (By et al., 2011; Borghi et al., 2002; Yoon et al., 2005). These controversial results might be associated with $A_{2 A R}$ intracellular signaling. $A_{2 A R}$ activation induces cAMP increased 
production (it can cause pain) and also $\mathrm{K}^{+}$channels opening (it can inhibit pain) (Jacobson \& Gao, 2006; Regaya et al., 2004; Sawynok, 1998).

$\mathrm{A}_{2 \mathrm{AR}}$ knockout animals are less sensitive to pain, suggesting that $\mathrm{A}_{2 \mathrm{AR}}$ is a pain facilitator in acute (Hussey et al., 2007) and chronic pain (Bura et al., 2008). Bura and coworkers (2008) also demonstrated that microglia and astrocytes expression was higher in wild-type $A_{2 A R}$ animals than in $\mathrm{A}_{2 \mathrm{AR}}$ knockout animals. Also, $\mathrm{A}_{2 \mathrm{AR}}$ located in glial cells is responsible for the release of inflammatory mediators that induce and maintain chronic pain (Boison et al., 2010). Thus, $A_{2 A R}$ blockade might be an interesting approach for future treatments of neuropathic and chronic pain. Meantime, also in chronic pain exists distinct results about $\mathrm{A}_{2 \mathrm{AR}}$. A report showed that only one spinal injection of $\mathrm{A}_{2 \mathrm{AR}}$ agonist was able to induce analgesia during several days in rats undergoing neuropathic pain (Loram et al., 2009). After all, it is clear that $A_{2 A R}$ is involved in pain modulation. However, more studies are necessary to precisely explain how this receptor works in distinct situations, only then it will be possible to make clinical approaches.

\section{6 $A_{2 B}$ receptors and pain}

Few studies have been evaluating the $A_{2 B R}$ role in pain. Most part of these studies showed that $A_{2 B R}$ facilitates pain transmission, because $A_{2 B R}$ antagonists have reduced pain (AboSalem et al., 2004; Bilkei-Gorzo et al., 2008; GodFrey et al., 2006). A2BR antagonist reduced thermal hyperalgesia and was able to potentiate the analgesic effect caused by morphine and acetaminophen (Abo-Salem et al., 2004; Godfrey et al., 2006). Also, the blockade of $A_{2 B R}$ presented an analgesic effect in inflammatory pain (Bilkei-Gorzo et al., 2008).

\section{7 $\mathrm{A}_{3}$ receptors and pain}

Similar to $A_{2 B R}$, adenosine $A_{3 R}$ is not an interesting target to pain relief. However, $A_{3 R}$ is implicated in pathological conditions such as ischemic diseases and in inflammation (for review see Borea et al., 2009). Regarding pain, there are few studies evaluating $A_{3 R}$ role. Sawynok and colleagues (1997) showed that $A_{3 R}$ activation causes pain and paw oedema through release of histamine and serotonin. $A_{3 R}$ knockout animals presented an increased pain threshold in some models of pain but not difference in others (Fedorova et al., 2003; $\mathrm{Wu}$ et al., 2002). $\mathrm{A}_{3 \mathrm{R}}$ might be an interesting target to inflammatory and autoimmune diseases, but not to pain states.

\subsection{Novel approaches in pain management involving adenosine receptors}

\subsubsection{Management of adenosine receptors by metabolism modulation}

The first report showing that adenosine kinase (AK) inhibition reduces behaviour associated to pain was published by Keil and DeLander, 1992. AK inhibitors are able to decrease pain levels when given peripherally or sistemically (Kowaluk et al., 1999; Lynch et al., 1999; Sawynok, 1998). Moreover, these inhibitors are efficacious against acute and chronic pain (Kowaluk et al., 2000; Lynch et al., 1999; McGaraughty et al., 2005; Poon \& Sawynok, 1998, 1999; Suzuki et al., 2001). Another enzyme that regulates adenosine level is adenosine deaminase (ADA), that converts adenosine to inosine (Sawynok, 1998). However, the analgesic effect caused by ADA inhibition is not so clear yet. It has been showed that 
inhibitors of ADA itself are able to cause analgesia in determined animal models (Poon \& Sawynok, 1999), but not in others (Keil \& DeLander, 1992, 1994).

Coadministration of AK and ADA inhibitors potentiates the analgesic effect of the former (Poon \& Sawynok, 1999). Also, adenosine effect is synergically augmented by coadministration of ADA inhibitor (Keil \& DeLander, 1994). Distinct effects between AK inhibitors and ADA inhibitors might be because adenosine has a higher affinity by AK than ADA (Arch \& Newsholme, 1978). In this point of view, AK seems to be the most important enzyme to regulate adenosine endogenous levels.

\subsubsection{Analgesic effect by supply of purinergic substrates}

Ecto-5'-nucleotidase (NT5E) is an enzyme located in the cell membrane that catalyzes the extracellular conversion of adenosine monophosphate (AMP) into adenosine in several tissues, included dorsal root ganglia (DRG) and substantia gelatinosa (Zylka, 2011). Recent studies have demonstrated that the analgesic effect of AMP combined with an AK inhibitor halved in NT5E knockout animals and is totally reversed in $\mathrm{A}_{1 \mathrm{R}}$ knockout animals (Sowa et al., 2010a). These results inspired another study that evaluated whether exogenous supply of NT5E (increases supply of adenosine) could induce a long lasting analgesic effect. NT5E presented effects that lasted for 2 days in models of inflammatory and chronic pain. Both effects were dependent on $\mathrm{A}_{1 \mathrm{R}}$ (Sowa, 2010b). Hence, the supply of enzymes that generate adenosine is a new interesting approach that may be used in studies to treat chronic pain.

\subsubsection{Involvement of adenosine receptors in acupuncture pain relief}

In an elegant study published in 2010, Goldman and colleagues showed that analgesia induced by acupuncture depends on purine release, such as ATP, ADP, AMP and adenosine. In addition, it has been showed that $\mathrm{A}_{1 \mathrm{R}}$ agonist replicates the acupuncture effect. Also, in $\mathrm{A}_{1 \mathrm{R}}$ knockout animals, acupuncture did not present analgesia. Moreover, inhibition of adenosine deaminase prolonged the analgesic effect of acupuncture in mice (Goldman et al., 2010). It is interesting to mention that caffeine, the most widely used drug across the world in beverages such as teas, coffee, mate, soft drinks, energy drinks and others is an antagonist of adenosine receptors. Therefore, patients in treatment with acupuncture should not drink these caffeine beverages, because caffeine might reduce the acupuncture analgesic effect (for review see Zylka, 2010).

\section{Inosine and pain}

\subsection{Inosine within of purinergic system}

ATP is the main molecule of purinergic system. Inside the cell, ATP may be bi-directionally converted into AMP. AMP is broken down into adenosine. Adenosine may be converted back into AMP through phosphorylation by AK. Moreover, adenosine might leave the cell by nucleoside transporter (NT). Inside the cell, adenosine deaminase is responsible for the conversion from adenosine to inosine. Outside the cell, this conversion is performed by ectoadenosine kinase or even adenosine deaminase. Inosine is a substrate to purine nucleoside phosphorylase (PNP), leading to hypoxanthines as its products. Hypoxanthines are converted into xanthines and afterwards to uric acid by xanthine oxidase (Figure 4) (See review Sawynok \& Liu, 2003). 


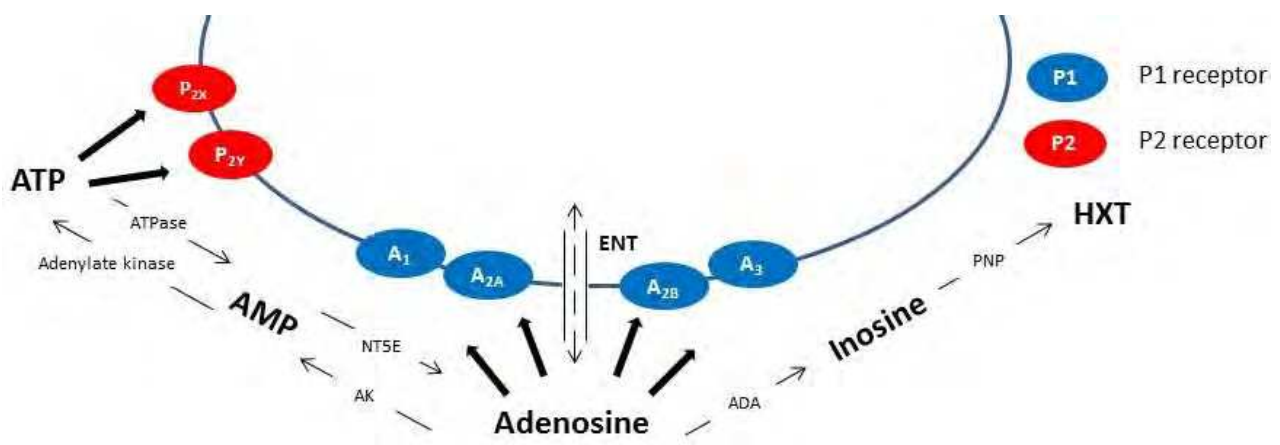

Fig. 4. Purinergic metabolism and its main molecules and enzymes. $A_{1}$, adenosine $A_{1}$ receptor; $A_{2 A}$, adenosine $A_{2 A}$ receptor; $A_{2 B}$, adenosine $A_{2 B}$ receptor; $A_{3}$, adenosine $A_{3}$ receptor $\mathrm{ADA}$, adenosine deaminase; $\mathrm{AK}$, adenosine kinase; $\mathrm{AMP}$, adenosine monophosphate; ATP, adenosine triphosphate; ENT, equilibrative nucleoside transporter; HXT, hypoxanthines; NT5E, ecto-5'nucleotidase; $\mathrm{P} 2 \mathrm{X}$, purine $\mathrm{P}_{2 \mathrm{X}}$ receptor; $\mathrm{P}_{2 \mathrm{Y}}$, purine $\mathrm{P}_{2 \mathrm{Y}}$ receptor; $\mathrm{PNP}$, purine nucleoside phosphorilase.

Thus, inosine is one among many molecules in purinergic system. However, inosine has specific roles in several physiological states, we will show some functions and discuss the role of inosine in pain control in next sections.

\subsection{Inosine physiological roles}

In recent decades, many physiological roles for inosine have been shown. During the 70's, Aviado demonstrated that inosine exerts cardiotonic actions, such as preventing negative inotropic effect and increasing coronary vasodilatation (Aviado, 1978). Also, inosine presents several effects on axonal growth, such as axon growth induction and damaged neurons stimulation (Benowitz et al., 1999, 2002; Chen et al., 2002). Inosine also induces a regrowth in axotomized retinal ganglion cells in rats (Wu et al., 2003). These data indicate that inosine may constitute a new approach to treat the injured or degenerated nerves in central or peripheral nervous system. Despite of cardiovascular and axonal growth effects, the inflammatory effects of inosine are the most studied. Inosine has significant antiinflammatory effects in several in vivo and in vitro models of inflammation (Gomez \& Sitkovsky, 2003; Haskó et al., 2000; Marton et al., 2001; Schneider et al., 2006). These effects seem to be mediated by $A_{1 R}, A_{2 R}$ and $A_{3 R}$ (Gomez \& Sitkovsky, 2003; Haskó et al., 2000, 2004).

\subsection{Inosine effect on acute pain}

Inosine has analgesic action when administered by different routes (i.e. intraperitoneal, oral, intrathecal or intracerebroventricular) against pain induced by acetic acid (Nascimento et al., 2010). Of note, inosine also inhibits pain induced by formalin. Formalin test induces 2 distinct types of pain, neurogenic phase (acute pain) and inflammatory phase (inflammatory pain). Inosine is not able to relieve pain in neurogenic phase. However, inosine reduces nearly totally the inflammatory pain in formalin test (Nascimento et al., 2010). The effects of inosine in this model of pain extended the acetic acid data because formalin is a more 
specific model. Therefore, these results indicate that inosine is able to prevent and reduce pain induced by inflammatory mediators. In this way, inosine may be inhibiting the synthesis or release of several neurotransmitters and mediators involved in pain conditions (Nascimento et al., 2010). We can also conclude that inosine is able to inhibit pain induced by central facilitation. Therefore, inosine increases pain threshold and it may be useful to treat some kinds of pain injury that result from a central sensitization. Adenosine receptors distribution on substantia gelatinosa, mainly $A_{1 R}$ and $A_{2 A R}$ could explain how inosine acts in this case (Sawynok, 1998; Sawynok \& Liu, 2003). Inosine also presents a significant and dose-related inhibition of pain induced by glutamate (acute pain model) injection into the paw of mice (Nascimento et al., 2010).

\subsection{Inosine effects on chronic pain}

The data described in literature strongly suggests that inosine may have an important effect in controlling chronic pain, since it has anti-inflammatory effect and can reduce acute pain. In fact, Nascimento and colleagues (2010) demonstrated that acute administration of inosine, intraperitoneally, was able to inhibit chronic inflammatory pain induced by CFA in mice, being effective up to 4 hours after administration. The CFA is responsible for inducing chronic inflammation by stimulating the body's immune response, this response is mediated by the synthesis and release of cytokines and inflammatory mediators (Zhang et al., 2011).

In the study published by Nascimento and colleagues (2010), inosine was effective against mechanical and thermal allodynia induced by partial sciatic nerve ligation (PSNL) up to 4 hours after treatment by intraperitoneal route. Further, in another experiment, inosine was given daily for until 22 days and it also presented significant analgesic effect. Pain induced by PSNL is very strong and may last for weeks (Ueda, 2006). Animal models of neuropathic pain induce many functional and biochemical changes in local injury site. After the surgery there is the release of multiple inflammatory and pain mediators which in turn, may also be present in other areas involved and affected by sciatic nerve, as spinal cord and brain (Bridges et al., 2001; Ji \& Woolf, 2001; Inoue et al., 2004; Ueda, 2006). Inosine activity in this kind of pain may indicate a promising molecule to new studies, because inosine might have a longer half-life than adenosine and admittedly does not have toxic or side effects.

\subsection{Adenosine receptors involved in analgesic effects of inosine}

$\mathrm{A}_{1 \mathrm{R}}$ has been considered the main receptor responsible for analgesic effect among adenosine receptors (Burnstock, 2007; Sawynok, 1998). $\mathrm{A}_{1 \mathrm{R}}$ is also the main receptor involved in inosine analgesic effect. Both $\mathrm{A}_{1 \mathrm{R}}$ antagonists DPCPX and 8-PT were able to reverse the inosine action. Inosine in a direct or indirect way activates $A_{1 R}$ to induce analgesia (Nascimento et al., 2010). Other studies have showed that adenosine receptor antagonists block in vivo and in vitro inosine effects (Haskó et al., 2000) and adenosine receptor knockout animals do not present immunoprotective effects of inosine (Gomez \& Sitkovsky, 2003). Thus, it is clear that the $A_{1 R}$ activation is essential for inosine to exert its effect (Figure 5).

Involvement of $A_{2 A R}$ in pain is quite controversial. Some studies show that $A_{2 A R}$ blockade leads to analgesic effect (Borghi et al., 2002; Yoon et al., 2005) while other studies demonstrate that the blockade or deletion of $\mathrm{A}_{2 \mathrm{AR}}$ causes pain relief (Bastia et al., 2002; Ledent et al., 1997). Inosine activates $A_{2 A R}$ to induce analgesia, at least in the acetic acid 
model (Nascimento et al., 2010). However, the participation of $A_{2 A R}$ receptor in inosine analgesia in other pain animal models might be different or does not exist. Moreover, the $\mathrm{A}_{2 \mathrm{AR}}$ involvement on inosine effect can occur due to its anti-inflammatory profile (Milne \& Palmer, 2011) and due to activation of the $\mathrm{K}^{+}$channels (Regaya et al., 2004).

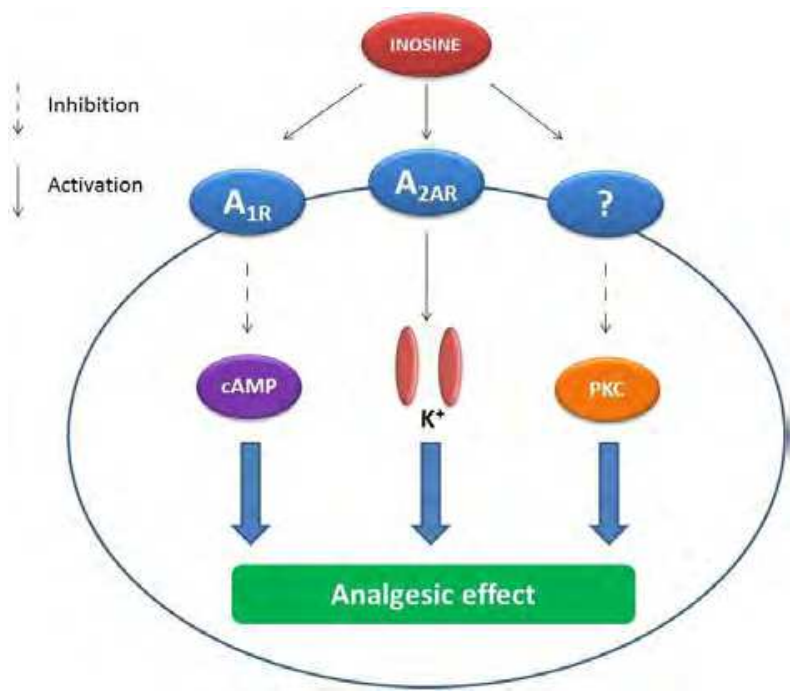

Fig. 5. Principal mechanisms of inosine antinociception. $A_{1 R}$, adenosine $A_{1}$ receptor; $A_{2 A R}$, adenosine $\mathrm{A}_{2 \mathrm{~A}}$ receptor, $\mathrm{AMP}$, cyclic adenosine monophosphate; $\mathrm{K}^{+}$, potassium channels; PKC, protein kinase $\mathrm{C}$.

$\mathrm{A}_{2 \mathrm{BR}}$ and $\mathrm{A}_{3 \mathrm{R}}$ adenosine receptors do not have significant role in pain transmission or modulation (Sawynok, 1998). Although it has been shown that inosine binds to $A_{3 R}$, it seems that $A_{2 B R}$ and $A_{3 R}$ receptors are not involved in inosine analgesic effect (Nascimento et al., 2010).

\subsubsection{Does inosine binds to adenosine receptor?}

Few studies have evaluated if inosine binds to adenosine receptor. Jin and co-workers demonstrated that inosine binds to $A_{3 R}$ in mast cells, but not to $A_{1 R}$ or $A_{2 A R}$ (Jin et al., 1997). In 2001, Fredholm's group observed that inosine weakly bound to $A_{1 R}$ and $A_{3 R}$, but not to $A_{2 R}$ (Fredholm et al., 2001). Fredholm concluded that inosine could not be considered a natural ligand of adenosine receptors. However, because of these few studies and considering in vivo studies where adenosine antagonists are able to block inosine effects, it is not is possible to affirm whether inosine is or not a natural ligand or a partial agonist of adenosine receptors. More studies are necessary to elucidate this issue.

\subsection{Intracellular signalling involved in analgesic effects of inosine}

The intracellular signaling involved in analgesic action of inosine is yet not entirely elucidated. Assuming that inosine effects depend on adenosine receptors, $A_{1 R}$ and $A_{2 A R}$, we can consider that adenosine receptors signaling pathways are the major effectors of this 
effect. As fully mentioned previously, $A_{1 R}$ is coupled to $\mathrm{Gi} / 0$ protein. $\mathrm{A}_{1 \mathrm{R}}$ signaling causes downstream inhibition of adenylyl cyclase and induction of PLC activity. Further, when $A_{1 R}$ is activated it causes potassium channel opening, PI3K and MAPK stimulation. All these pathways might participate in the inosine analgesic effect (Ansari et al., 2009; Jacobson \& Gao, 2006; Sawynok, 1998; Schulte \& Fredholm, 2003). Inosine inhibits the pain caused by PKC activator. Thus, at least in part, the analgesic action of inosine depends on PKC inhibition (Nascimento et al., 2010), even though it is not clear yet how it happens (Figure 5). Costenla and coworkers showed that an adenosine analog that has preference for $\mathrm{A}_{2 \mathrm{AR}}$ is able to inhibit sodium current in NMDA receptors (Costenla et al., 1999). This signaling occurring in vivo could partially explain how $\mathrm{A}_{2 \mathrm{AR}}$ works in analgesia induced by inosine.

\subsection{Perspectives}

As previously described in this chapter, purinergic system is an important endogenous modulator of pain. Hundreds of pre-clinical studies targeting the adenosine receptors showed analgesic effect in distinct pain models. Inosine, an endogenous modulator of several physiological functions also presents a role in pain transmission. Inosine might be a natural activator of adenosine receptors. Also, it can indirectly increase the release or reduce the uptake of adenosine, potentiating the effect of its precursor. Thus, understanding how inosine acts to induce analgesia may help discover new ways to inhibit pain or new therapeutic targets. Moreover, inosine may be a potential molecule to treat pain, and it has a great advantage to be devoid of toxic or side effects because it has been used clinically for many years for other purposes. Another interesting approach would be to attempt to prolong and potentiate the effect of inosine. For this, a great understanding of purinergic metabolism is necessary in order to correctly and effectively approach this matter.

\section{Active drugs on adenosine receptors and their clinical applications}

Nowadays there is increasing interest in the therapeutic potential of adenosinergic compounds (including receptor agonists and antagonists, enzyme inhibitors and others), and many adenosine compounds have been evaluated.

\subsection{Adenosine receptor ligands and their potential as novel drugs}

Adenosine itself, for a long time, was the only adenosine agonist used in humans. It is widely used in the treatment of paroxysmal supraventricular tachycardia (Adenocard ${ }^{\circledR}$ ) due to its activation of $A_{1 R}$, and as a diagnostic for myocardial perfusion imaging (Adenoscan ${ }^{\circledR}$ ) utilizing its $A_{2 A R}$-activating effects resulting in vasodilation (Müller \& Jacobson, 2011). However, other $\mathrm{A}_{1 \mathrm{R}}$-selective agonists such as Selodenoson, Capadenoson e Tecadenoson have been clinically evaluated for the treatment of paroxysmal supraventricular tachycardia, atrial fibrillation, or angina pectoris (Müller \& Jacobson, 2011). Still talking about cardiovascular disorders, selective $\mathrm{A}_{2 \mathrm{AR}}$ agonist, Apadenoson, Binodenoson and Sonedenoson appears as candidates for clinical use (Awad et al., 2006; Desai et al., 2005; Udelson et al. 2004). These agonists are of interest as vasodilator agents in cardiac imaging (Cerqueira, 2006) and inflammation suppressors. Accordingly, Regadenoson is already approved for diagnostic imaging (Iskandrian et al., 2007). $A_{3 R}$ selective agonists are also currently in clinical trials and exhibit nanomolar affinity at the receptor, CF101 (Can-Fite Biopharma) and Cl-IB-MECA (CF102) are in trials for autoimmune inflammatory disorders 
and for liver cancer, respectively. Two other $A_{3 R}$ agonists CP-608,039 and its N6-(2,5dichlorobenzyl) analogue CP-532,903 were previously under development for cardioprotection. MRS3558 (CF502) is in preclinical development for the treatment of autoimmune disease (Avni et al., 2010; Wan et al., 2008).

\subsection{Adenosinergic drugs in pain clinical studies and practical}

Clinical studies confirm the pre-clinical trials showing that in neuropathic pain patients, adenosine was able to alleviate spontaneous pain, tactile and thermal allodynia, as well as thermal hyperalgesia (Qu et al., 1997). In addition, intravenous infusion of adenosine during breast surgery reduced the postoperative pain (Lynch et al., 2003; Sollevi et al., 1995). Spinal administration of adenosine and adenosine analogs in humans also exhibited analgesic effect. A phase I clinical safety study in healthy volunteers demonstrated that $1000 \mu \mathrm{g}$ of adenosine given intrathecally lacked side effects and led to a significant decrease in mustard oil-induced inflammatory pain, in tourniquet induced ischemic pain, and decreased areas of secondary allodynia after skin inflammation (Rane et al., 1998).

In another study, a single dose of $0.1-0.5 \mathrm{mg} / \mathrm{kg}$ of SDZ WAG 994 (adenosine $\mathrm{A}_{1 \mathrm{R}}$ agonist), was evaluated in a phase I clinical study, and this compound was well tolerated. A dose of 1 $\mathrm{mg} / \mathrm{kg}$ was used in a randomized double-blind clinical trial to determine its efficacy in postoperative dental pain after third molar surgery. However, SDZ WAG 994 did not show significant difference from placebo and was not effective in attenuating postoperative pain after third molar surgery. On the other hand, at higher doses, the compound showed dosedependent adverse events (Seymour et al., 1999; Wagner et al., 1995; Yan et al., 2003).

Another full high-affinity $\mathrm{A}_{1 \mathrm{R}}$ agonists, GR79236X, was also evaluated in patients with dental pain after third molar extraction. Patients received a 15-min double-blind infusion containing $10 \mu \mathrm{g} / \mathrm{kg}$ of GR79236X, unfortunately, no evidence of efficacy of GR79236X was observed with this compound compared with placebo (Sneyd et al., 2007). Another $A_{1 R}$ agonist GW493838 developed by GlaxoSmithKline, was evaluated in phase II clinical trials to determine its analgesic effect in patients with postherpetic neuralgia or peripheral nerve injury caused by trauma or surgery. However, further development of GW493838 has been discontinued (Nelsen et al., 2004; as cited in Elzein \& Zablocki, 2008).

Allosteric modulation of $\mathrm{A}_{1 \mathrm{R}}$ function may also be an interesting tool. Accordingly, the $\mathrm{A}_{1 \mathrm{R}^{-}}$ selective allosteric enhancer T-62, given orally was also shown to reduce hypersensitivity in carrageenan-inflamed rats, in addition, phase I clinical trials of T62 have been completed as a treatment for neuropathic pain (Childers et al., 2005). Therewithal, the $A_{2 A R}$ agonist BVT.115959 from Biovitrum completed the clinical trials for diabetic neuropathic pain and it was well tolerated but did not significantly improve pain symptoms (Biovitrum, 2005; Zylka, 2011).

\section{Conclusion and future directions}

This chapter presented a general and updated review about the purinergic system with emphasis in adenosine receptors (P1) and pain. It is possible to conclude that the modulation of this system and its receptors is quite important and interesting for the control of pain. Recent studies have approached this system in new ways and contributed to the development of this research field. Some clinical studies have been carried out with 
purinergic drugs (adenosine analogs) and some studies have showed quite satisfactory effects, although others haven't showed statistical difference between treated and nontreated groups. Finally, the possibility of new drugs targeting the purinergic system to treat distinct kinds of pain reaching clinical trials in the next years is clear.

\section{References}

Abbracchio, MP. \& Burnstock, G. (1994). Purinoceptores: are there families of P2X and P2Y purinoceptores? Pharmacology \& Therapeutics, Vol. 64, No.3, pp. (445-475)

Abbracchio, MP., Brambilla, R., Ceruti, S., Kim, HO., von Lubitz, DK., Jacobson, KA. \& Cattabeni, F. (1995). G protein-dependent activation of phospholipase C by adenosine A3 receptors in rat brain. Molecular Pharmacology, Vol.48, No. 6, (December, 1995), pp.(1038-1045), ISSN 1038-1045.

Abo-Salem, OM., Hayallah, AM., Bilkei-Gorzo, A., Filipek, B., Zimmer, A. \& Müller, CE. (2004). Antinociceptive effects of novel A2B adenosine receptor antagonists. The Journal of Pharmacology Experimental Therapeutics, Vol 308, No. 1, (January, 2004), pp. (358-66), ISSN 1521-0103.

Ansari, HR., Teng, B., Nadeem, A., Roush, KP., Martin, KH., Schnermann, J., \& Mustafa, SJ. (2009). A(1) adenosine receptor-mediated PKC and p42/p44 MAPK signaling in mouse coronary artery smooth muscle cells. American Journal of Physiology. Heart and Circulatory Physiology, Vol. 297, No 3, (September, 2009), pp. (H1032-H1039), ISSN 1522-1539.

Arch, JR. \& Newsholme, EA. (1978). Activities and some properties of 5'-nucleotidase, adenosine kinase and adenosine deaminase in tissues from vertebrates and invertebrates in relation to the control of the concentration and the physiological role of adenosine. The Biochemical Journal, Vol. 174, No 3, (September, 1978), pp. (965-977).

Armstrong, SC. \& Ganote, E. (1994). Adenosine receptor specificity in preconditioning of isolated rabbit cardiomyocytes: evidence of A3 receptor involvement. Cardiovascular Research, Vol. 28, No. 7, (July, 1994) pp. (1049-1056).

Aviado, DM. (1978). Effects of fluorocarbons, chlorinated solvents, and inosine on the cardiopulmonary ystem. Environmental Health Perspectives, Vol. 26, No. 1, (October, 1978), pp. (207-215).

Avni, HJ., Garzozi, IS., Barequet, F., Segev, F., Varssano, D., Sartani, G., Chetrit, N., Bakshi, E., Zadok, D., Tomkins, O., Litvin, G., Jacobson, KA., Fishman, S., Harpaz, Z., Farbstein, M., Yehuda, SB., Silverman, MH., Kerns, WD., Bristol, DR., Cohn, I. \& Fishman, P. (2010). Treatment of dry eye syndrome with orally-administered CF101: data from a phase 2 clinical trial, Ophthalmology, Vol. 117, No. 7, (July, 2010), pp. (1287-1293).

Awad, AS., Huang, L., Ye, H., Duong, ET., Bolton, WK., Linden, J. \& Okusa, MD. (2006). Adenosine A2A receptor activation attenuates inflammation and injury in diabetic nephropathy. American Journal of Physiology. Renal Physiology, Vol. 290, No. 4, (April, 2006), pp. (F828-F837).

Bastia, E., Varani, K., Monopoli, A. \& Bertorelli R (2002). Effects of A(1) and A(2A) adenosine receptor ligands in mouse acute models of pain. Neuroscience Letters, Vol. 328, No. 3, (August, 2002), pp. (241-244). 
Benowitz, LI., Goldberg, DE. \& Irwin, N. (2002). Inosine stimulates axon growth in vitro and in the adult CNS. Progress in Brain Research, Vol. 137, No. 1, pp. (389-399).

Benowitz, LI., Goldberg, DE., Madsen, JR., Soni, D. \& Irwin, N. (1999). Inosine stimulates extensive axon collateral growth in the rat corticospinal tract after injury. Proceedings of the National Academy Sciences of the United States of America, Vol. 96, No. 23, (November, 1999), pp. (13486-13490).

Bilkei-Gorzo, A., Abo-Salem, OM., Hayallah, AM., Michel, K., Müller, CE. \& Zimmer, A. (2008). Adenosine receptor subtype-selective antagonists in inflammation and hyperalgesia. Naunyn- Schmiedebergs Archives of Pharmacology, Vol. 377, No. 1, (March, 2008), pp. (65-76).

Biovitrum, (January, 2008). A Double-Blind, Placebo-Controlled, Randomized, ParallelGroup Study Evaluating the Efficacy and Tolerability of Oral BVT.115959, a Novel A2A Agonist, Versus Placebo in the Treatment of Diabetic Neuropathic Pain, 08.25.2011, Available from

http:/ / www.clinicaltrials.gov/ct2/ show /NCT00452777?term=Efficacy+and+toler ability+of+novel+A2A+agonist+in+treatment+of+diabetic+neuropathic+pain\&ran $\mathrm{k}=1$

Boison, D., Chen, JF. \& Fredholm, BB. (2010). Adenosine signaling and function in glial cells. Cell Death Differentiation, Vol. 17, No. 7, (July, 2010), pp. (1071-1082).

Borea, PA., Gessi, S., Bar-Yehuda, S. \& Fishman, P. (2009). A3 adenosine receptor: pharmacology and role in disease. Handbook of Experimental Pharmacology, Vol. 193, No. 1, pp. (297-327).

Borghi, V., Przewlocka, B., Labuz, D., Maj, M., Ilona, O. \& Pavone, F. (2002). Formalininduced pain and mu-opioid receptor density in brain and spinal cord are modulated by A1 and A2a adenosine agonists in mice. Brain Research, Vol. 956, No. 2, (November, 2002), pp. (339-348).

Bridges, D., Thompson SW. \& Rice, AS. (2001). Mechanisms of neuropathic pain. British Journal of Anaesthesia, Vol. 87, No. 1, (July, 2001), pp. (12-26), ISSN 1471-67

Bura, SA., Nadal, X., Ledent, C., Maldonado, R. \& Valverde, O. (2008). A2A adenosine receptor regulates glia proliferation and pain after peripheral nerve injury. Pain, Vol. 140, No. 1, (November, 2008), pp. (95-103).

Burnstock, G. (1972). Purinergic nerves. Pharmacological Reviews, Vol. 24, No. 3, (September, 1972), pp. (509-581), ISSN: 1521-0081

Burnstock, G. (1978). A basis for distinguishing two types of purinergic receptor, In: Cell Membrane Receptors for Drugs and Hormones: A Multidisciplinary Approach, Straub, RW. \& Bolis L., pp. (107-118), Raven Press, New York.

Burnstock, G. (2007). Purine and pyrimidine receptors. Cellular and Molecular Life Sciences, Vol. 64, No. 12, (June, 2007), pp. (1471-1483).

Burnstock, G. (2008). Purinergic signalling and disorders of the central nervous system. Nature Reviews. Drug Discovery, Vol. 7, No. 7, (July, 2008), pp. (575-590), ISSN: 14741784

Burnstock, G. \& Kennedy, C. (1985). Is there a basis for distinguishing two types of P2purinoceptor? General Pharmacology, Vol. 16, No. 5, pp. (433-440).

Burnstock, G. \& Knight, GE. (2004). Cellular distribution and functions of P2 receptor subtypes in different systems. International Review of Cytology, Vol. 240, No.1, pp. (31-304). 
Burnstock, G. \& Williams, M. (2000). P2 purinergic receptors: modulation of cell function and therapeutic potential. The Journal of Pharmacology and Experimental Therapeutics, Vol. (295), No. 3, (December, 2000), pp. (862-869), ISSN 1521-0103

Burnstock, G., Fredholm, BB. \& Verkhratsky, A. (2011). Adenosine and ATP receptors in the brain. Current Topics in Medicinal Chemistry, Vol.11, No.8, (April, 2011), pp. (9731011), ISSN: 1568-0266

By, Y., Condo, J., Durand-Gorde, JM., Lejeune, PJ., Mallet, B., Guieu, R. \& Ruf, J. (2011). Intracerebroventricular injection of an agonist-like monoclonal antibody to adenosine $\mathrm{A}(2 \mathrm{~A})$ receptor has antinociceptive effects in mice. Journal of Neuroimmunology, Vol. 230, No. 1-2, (January, 2011), pp. (178-182).

Cerqueira, MD. (2006). Advances in pharmacologic agents in imaging: new A2A receptor agonists. Current Cardiology Reports, Vol. 8, No. 2, (March, 2006), pp. (119-122).

Chen, P., Goldberg, DE., Kolb, B., Lanser, M. \& Benowitz, LI. (2002). Inosine induces axonal rewiring and improves behavioral outcome after stroke. Proceedings of the National Academy of Sciences of the United States of America, Vol. 99, No. 13, (June, 2002), pp. (9031-9036).

Childers, SR., Li, X., Xiao, R. \& Eisenach, JC. (2005). Allosteric modulation of adenosine A1 receptor coupling to G-proteins in brain. Journal of Neurochemistry, Vol. 93, No.3, (May, 2005), pp. (715 -723).

Choca, JI., Green, RD. \& Proudfit, HK. (1988). Adenosine A1 and A2 receptors of the substantia gelatinosa are located predominantly on intrinsic neurons: an autoradiography study. Journal of Pharmacology and Experimental Therapeutics, Vol. 247, No. 2, (November, 1988), pp. (757-764), ISSN: 1521-0103

Costenla, AR., De Mendonca, A., Sebastião, A. \& Ribeiro, JA. (1999). An adenosine analogue inhibits NMDA receptor-mediated responses in bipolar cells of the rat retina. Experimental Eye Research, Vol. 68, No. 3, (March, 1999), pp. (367-70).

Cunha, RA., Ferre, S., Vaugeois, JM. \& Chen, JF. (2008). Potential therapeutic interest of adenosine A2A receptors in psychiatric disorders. Current Pharmaceutical Design, Vol. 14, No. 15, (May, 2008), pp. (1512-1524), ISSN: 1381-6128

Curros-Criado, MM. \& Herrero, JF. (2005). The antinociceptive effects of the systemic adenosine A1 receptor agonist CPA in the absence and in the presence of spinal cord sensitization. Pharmacology, Biochemistry and Behaviour, Vol. 82, No. 4, (December, 2005), pp. (721-726).

DeLander, GE. \& Hopkins, CJ. (1986). Spinal adenosine modulates descending antinociceptive pathways stimulated by morphine. Journal of Pharmacology and Experimental Therapeutics, Vol.239, No. 1, (October, 1986), pp. (88-93), ISSN 15210103

Desai, C., Victor-Veja, S., Gadangi, S., Montesinos, MC., Chu, CC. \& Cronstein, BN. (2005). Adenosine A2A receptor stimulation increases angiogenesis by down-regulating production of the antiangiogenic matrix protein thrombospondin 1. Molecular Pharmacology, Vol. 67, No. 5, (May, 2005), pp. (1406-1413), ISSN: 1521-0111

Dixon, AK., Gubitz, AK., Sirinathsinghji, DJ., Richardson, PJ. \& Freeman, TC. (1996). Tissue distribution of adenosine receptor mRNAs in the rat. British Journal of Pharmacology, Vol. 118, No. 6, (July, 1996), pp. (1461-1468). 
Doak, GJ. \& Sawynok, J. (1995). Complex role of peripheral adenosine in the genesis of the response to subcutaneous formalin in the rat. European Journal of Pharmacology, Vol. 281, No. 3, (August, 1995), pp. (311-318).

Drury, AN. \& Szent-Györgyi, A. (1929). The physiological activity of adenine compounds with special reference to their action upon the mammalian heart. The Journal of Physiology, Vol. 68, No. 3, (November, 1929), pp. (213-237).

Elzein, E. \& Zablocki, J. (2008). A1 adenosine receptor agonists and their potential therapeutic applications. Expert Opinion on Investigational Drugs, Vol. 17, No. 12, (December, 2008), pp. (1901-1910).

Fedorova, IM., Jacobson, MA., Basile, A. \& Jacobson, KA. (2003). Behavioral characterization of mice lacking the A3 adenosine receptor: sensitivity to hypoxic neurodegeneration. Cellular and Molecular Neurobiology, Vol. 23, No. 3, (June, 2003), pp. (431-447).

Feoktistov, I. \& Biaggioni, I. (2011). Role of adenosine A(2B) receptors in inflammation. Advaces in Pharmacology, Vol. 61, No. 1, pp. (115-144).

Fredholm, BB. (1995). Purinoceptors in the nervous system. Pharmacology $\mathcal{E}$ Toxicology, Vol. 76, No. 4, (April, 1995), pp. (228-239).

Fredholm, BB., Cunha, RA. \& Svenningsson, P. (2003). Pharmacology of adenosine A2A receptors and therapeutic applications. Current Topics in Medicinal Chemistry, Vol. 3, No. 4, (February, 2003), pp. (413-426), ISSN 1568-0266

Fredholm, BB., Chern, Y., Franco, R. \& Sitkovsky, M. (2007). Aspects of the general biology of adenosine A2A signaling. Progress in Neurobiology, Vol. 83, No 5, (December, 2007), pp. (263-276).

Fredholm, BB., IJzerman, AP., Jacobson, KA., Linden, J. and Muller, CE. (2011). International Union of Basic and Clinical Pharmacology. LXXXI. Nomenclature and classification of adenosine receptors- an update. Pharmacological Reviews, Vol.63, No. 1, (March, 2011), pp. (1-34), ISSN 1521-0081

Fredholm, BB., Irenius, E., Kull, B. \& Schulte, G. (2001). Comparison of the potency of adenosine as an agonist at human adenosine receptors expressed in Chinese hamster ovary cells. Biochemical Pharmacology, Vol. 61, No. 4, (February, 2001), pp. (443-448).

Godfrey, L., Yan, L., Clarke, GD., Ledent, C., Kitchen, I. \& Hourani, SM. (2006). Modulation of paracetamol antinociception by caffeine and by selective adenosine A2 receptor antagonists in mice. European Journal of Pharmacology, Vol. 531, No.1-3, (February, 2006), pp. (80-86).

Goldman, N., Chen, M., Fujita, T., Xu, Q., Peng, W., Liu, W., Jensen, TK., Pei, Y., Wang, F., Han, X., Chen, JF., Schnermann, J., Takano, T., Bekar, L., Tieu, K. \& Nedergaard, M. (2010). Adenosine A1 receptors mediate local anti-nociceptive effects of acupuncture. Nature Neuroscience, Vol. 13, No. 7, (July, 2010), pp. (883-888), ISSN 1546-1726

Gomez, G. \& Sitkovsky, MV. (2003). Differential requirement for A2a and A3 adenosine receptors for the protective effect of inosine in vivo. Blood, Vol. 102, No. 13, (December, 2003), pp. (4472-4478), ISSN 1528-0020

Gong, QJ., Li, YY., Xin, WJ., Wei, XH., Cui, Y., Wang, J., Liu, Y., Liu, CC., Li, YY. \& Liu, XG. (2010). Differential effects of adenosine A1 receptor on pain-related behavior in 
normal and nerve-injured rats. Brain Research, Vol. 1361, (November, 2010), pp. (2330).

Haskó, G., Kuhel, DG., Németh, ZH., Mabley, JG., Stachlewitz, RF., Virág, L., Lohinai, Z., Southan, GJ., Salzman, AL. \& Szabó, C. (2000). Inosine inhibits inflammatory cytokine production by a posttranscriptional mechanism and protects against endotoxin-induced shock. Journal of Immunology, Vol. 164, No. 2, (January, 2000), pp. (1013-1019), ISSN 1550-6606

Haskó, G., Sitkovsky, MV. \& Szabó, C. (2004). Immunomodulatory and neuroprotective effects of inosine. Trends in Pharmacological Science, Vol. 25, No. 3, (March, 2004), pp. (152-157).

Horiuchi, H., Ogata, T., Morino, T. \& Yamamoto, H. (2010). Adenosine A1 receptor agonists reduce hyperalgesia after spinal cord injury in rats. Spinal Cord, Vol. 48, No. 9, (September, 2010), pp. (685-690), ISSN 1476-5624

Hussey, MJ., Clarke, GD., Ledent, C., Hourani, SM. \& Kitchen, I. (2007). Reduced response to the formalin test and lowered spinal NMDA glutamate receptor binding in adenosine A2A receptor knockout mice. Pain, Vol. 129, No. 3, (June, 2007), pp. (287294).

Hwang, JH., Hwang, GS., Cho, SK. \& Han, SM. (2005). Morphine can enhance the antiallodynic effect of intrathecal R-PIA in rats with nerve ligation injury. Anesthesia $\mathcal{E}$ Analgesia, Vol. 100, No 2, (February, 2005), pp. (461-468), ISSN 1526-7598

Inoue, M., Rashid, MH., Fujita, R., Contos, JJ., Chun, J. \& Ueda, H. (2004). Initiation of neuropathic pain requires lysophosphatidic acid receptor signaling. Nature Medicine, Vol. 10, No. 7, (July, 2004), pp. (712-718), ISSN 1546-170X

Iskandrian, AE., Bateman, TM., Belardinelli, L., Blackburn, B., Cerqueira, MD., Hendel, RC., Lieu, H., Mahmarian, JJ., Olmsted, A., Underwood, SR., Vitola, J. \& Wang, W. (2007). Adenosine versus regadenoson comparative evaluation in myocardial perfusion imaging: results of the ADVANCE phase 3 multicenter international trial. Journal of Nuclear Cardiology, Vol. 14, No. 5, (September, 2007) pp. (645-658).

Jacobson, KA. \& Gao, GZ. (2006). Adenosine receptors as therapeutic targets. Nature Reviews. Drug Discovery, Vol. 5, No. 3, (March, 2006), pp. (247-264), ISSN 1474-1784

Ji, RR. \& Woolf, CJ. (2001). Neuronal plasticity and signal transduction in nociceptive neurons: implications for the initiation and maintenance of pathological pain. Neurobiology of Disease, Vol. 8, No. 1, (February, 2001), pp. (1-10).

Jin, X., Shepherd, RK., Duling, BR. \& Linden, J. (1997). Inosine binds to A3 adenosine receptors and stimulates mast cell degranulation. The Journal of Clinical Investigation, Vol. 100, No. 11, pp. (2849-2857).

Johansson, B., Halldner, L., Dunwiddie, TV., Masino, SA., Poelchen, W., Giménez-Llort, L., Escorihuela, RM., Fernández-Teruel, A., Wiesenfeld-Hallin, Z., Xu, XJ., Hardemark, A., Betsholtz, C., Herlenius, E. \& Fredholm, BB. (2001). Hyperalgesia, anxiety, and decreased hypoxic neuroprotection in mice lacking the adenosine A1 receptor. Proceedings of the National Academy of Sciences of the United States of America, Vol. 98, No. 16, (July, 2001), pp. (9407-9412).

Karlsten, R., Gordh, T. \& Post, C. (1992). Local antinociceptive and hyperalgesic effects in the formalin test after peripheral administration of adenosine analogues in mice. Pharmacology \& Toxicology, Vol. 70, No. 6 Pt 1, (June, 1992), pp. (434-438). 
Keil, GJ 2nd. \& DeLander, GE. (1992). Spinally-mediated antinociception is induced in mice by an adenosine kinase-, but not by an adenosine deaminase-, inhibitor. Life Sciences, Vol. 51, No. 19, pp. (PL171 - PL176).

Keil, GJ 2nd. \& DeLander, GE. (1994). Adenosine kinase and adenosine deaminase inhibition modulate spinal adenosine- and opioid agonist-induced antinociception in mice. European Journal of Pharmacology, Vol. 271, No. 1, (December, 1994), pp. (37-46).

Kowaluk, EA., Mikusa, J., Wismer, CT., Zhu, CZ., Schweitzer, E., Lynch, JJ., Lee, CH., Jiang, M., Bhagwat, SS., Gomtsyan, A., McKie, J., Cox, BF., Polakowski, J., Reinhart, G., Williams, M. \& Jarvis, MF. (2000). ABT-702 (4-amino-5-(3-bromophenyl)-7-(6morpholino-pyridin- 3-yl)pyrido[2,3-d]pyrimidine), a novel orally effective adenosine kinase inhibitor with analgesic and anti-inflammatory properties. II. In vivo characterization in the rat. Journal of Pharmacology and Experimental Therapeutics, Vol. 295, No. 3, (December, 2000), pp. (1165-1174).

Kowaluk, EA., Kohlhaas, KL., Bannon, A., Gunther, K., Lynch, JJ 3rd. \& Jarvis, MF. (1999). Characterization of the effects of adenosine kinase inhibitors on acute thermal nociception in mice. Pharmacology, Biochemitry E Behaviour, Vol. 63, No. 1, (May, 1999), pp. (83-91).

Ledent, C., Vaugeois, JM., Schiffmann, SN., Pedrazzini, T., El Yacoubi, M., Vanderhaeghen, JJ., Costentin, J., Heath, JK., Vassart, G. \& Parmentier, M. (1997). Aggressiveness, hypoalgesia and high blood pressure in mice lacking the adenosine A2a receptor. Nature, Vol. 388, No. 6643, pp. (674-678), ISSN 1476-4687

Li, X., Conklin, D., Pan, HL. \& Eisenach, JC. (2003). Allosteric adenosine receptor modulation reduces hypersensitivity following peripheral inflammation by a central mechanism. The Journal of Pharmacology and Experimental Therapeutics, Vol. 305, No. 3, (June, 2003), pp. (950-955), ISSN 1521-0103

Lima, FO., Souza, GR., Verri, WA Jr., Parada, CA., Ferreira, SH., Cunha, FQ. \& Cunha, TM. (2010). Direct blockade of inflammatory hypernociception by peripheral A1 adenosine receptors: involvement of the NO/cGMP/PKG/KATP signaling pathway. Pain, Vol. 151, No. 2, (November, 2009), pp. (506-515).

Loram, LC., Harrison, JA., Sloane, EM., Hutchinson, MR., Sholar, P., Taylor, FR., Berkelhammer, D., Coats, BD., Poole, S., Milligan, ED., Maier, SF., Rieger, J. \&Watkins, LR. (2009). Enduring reversal of neuropathic pain by a single intrathecal injection of adenosine 2A receptor agonists: a novel therapy for neuropathic pain. The Journal of Neuroscience, Vol. 29, No. 44, (November, 2009), pp. (14015-14025), ISSN 1529-2401

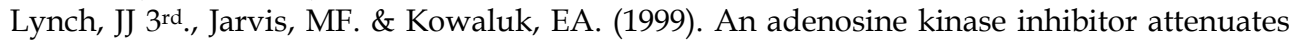
tactile allodynia in a rat model of diabetic neuropathic pain. European Journal of Pharmacology, Vol. 364, No.2-3, (January, 1999), pp. (141-146).

Lynch, ME., Clark, AJ. \& Sawyonk, J. (2003). Intravenous adenosine alleviates neuropathic pain: a double blind placebo controlled crossover trial using an enriched enrollment design. Pain, Vol. 103, No. (1-2), (May, 2003), pp. (111 -117).

Marton, A., Pacher, P., Murthy, KG., Németh, ZH., Haskó, G. \& Szabó, C. (2001). Antiinflammatory effects of inosine in human monocytes, neutrophils and epithelial cells in vitro. International Journal of Molecular Medicine, Vol. 8, No. 6, (December, 2001), pp. (617-621). 
The Involvement of Purinergic System in Pain:

McGaraughty, S. \& Jarvis, MF. (2006). Purinergic control of neuropathic pain. Drug Development Research, Vol. 67, No. 4, (April, 2006), pp. (376-388).

McGaraughty, S., Cowart, M., Jarvis, MF. \& Berman, RF. (2005). Anticonvulsant and antinociceptive actions of novel adenosine kinase inhibitors. Current Topics Medicinal Chemistry, Vol. 5, No. 1, pp. (43-58). ISSN: 1568-0266

Megson, AC., Dickenson, JM., Townsend-Nicholson, A. \& Hill, SJ. (1995). Synergy between the inositol phosphate responses to transfected human adenosine A1-receptors and constitutive P2-purinoceptors in CHO-K1 cells. British Journal of Pharmacology, Vol. 115, No. 8, (August, 1995), pp. (1415-14124).

Milne, GR. \& Palmer, TM. (2011). Anti-inflammatory and immunosuppressive effects of the A2A adenosine receptor. The Scientific World Journal, Vol. 11, No. 1, (February, 2011), pp. (320-339).

Müller, CE. \& Jacobson, KA. (2011). Recent developments in adenosine receptor ligands and their potential as novel drugs. Biochimica et Biophysica Acta, Vol. 1808, No. 5, (May, 2011), pp. (1290-1308).

Nascimento, FP., Figueredo, SM., Marcon, R., Martins, DF., Macedo, SJ Jr., Lima, DA., Almeida, RC., Ostroski, RM., Rodrigues, AL. \& Santos, ARS. (2010). Inosine reduces pain-related behavior in mice: involvement of adenosine A1 and A2A receptor subtypes and protein kinase $\mathrm{C}$ pathways. The Journal of Pharmacology and Experimental Therapetics, Vol. 334, No. 2, (May, 2010), pp. (590-598), ISSN: 1521-0101

Palmer, TM., Benovic, JL. \& Stiles, GL. (1995). Agonist-dependent phosphorylation and desensitization of the rat A3 adenosine receptor. Evidence for a G-protein-coupled receptor kinase-mediated mechanism. The Journal of Biological Chemistry, Vol. 270, No. 49, (December, 1995), pp. (29607-29613), ISSN: 1083-351-X

Peakman, MC. \& Hill, SJ. (1994). Adenosine A2B-receptor-mediated cyclic AMP accumulation in primary rat astrocytes. British Journal of Pharmacology, Vol. 111, No. 1, (January, 1994), pp. (191-198)

Poon, A. \& Sawynok, J. (1999). Antinociceptive and anti-inflammatory properties of an adenosine kinase inhibitor and an adenosine deaminase inhibitor. European Journal of Pharmacology, Vol. 384, No. 2-3, (November, 1999), pp. (123-38)

Poon, A. \& Sawynok, J. (1998). Antinociception by adenosine analogs and inhibitors of adenosine metabolism in an inflammatory thermal hyperalgesia model in the rat. Pain, Vol. 74, No. 2-3, (January, 1998), pp. (235-245)

Qu, X., Cooney, G. \& Donnelly, R. (1997). Short-term metabolic and haemodynamic effects of GR79236 in normal and fructose-fed rats. European Journal of Pharmacology, Vol. 338, No. 3, (November, 1997), pp. (269-276)

Ralevic, V. \& Burnstock, G. (1998). Receptors for purines and pyrimidines. Pharmacological Reviews, Vol. 50, No. 3, (September, 1998), pp. (413-492). ISSN: 1521-0081

Rane, K., Segerdahl, M., Goiny, M. \& Sollevi, A. (1998). Intrathecal adenosine administration, a phase 1 clinical safety study in healthy volunteers, with additional evaluation of its influence on sensory thresholds and experimental pain. Anesthesiology, Vol. 89, No. 5, (November, 1998), pp. (1108-1115).

Regaya, I., Pham, T., Andreotti, N., Sauze, N., Carrega, L., Martin-Eauclaire, MF., Jouirou, B., Peragut, JC., Vacher, H., Rochat, H., Devaux, C., Sabatier, JM. \& Guieu, R. (2004). Small conductance calcium-activated $\mathrm{K}+$ channels, SkCa, but not voltagegated $\mathrm{K}+(\mathrm{Kv})$ channels, are implicated in the antinociception induced by 
CGS21680, a A2A adenosine receptor agonist. Life Sciences, Vol. 76, No. 4, (December, 2004), pp. (367-377).

Ribeiro, JA., Sebastiao, AM. \& de Mendonça, A. (2002). Adenosine receptors in the nervous system: pathophysiological implications. Progress in Neurobiology, Vol. 68, No. 6, (December, 2002), pp. (377-392).

Salvatore, CA., Jacobson, MA., Taylor, HE., Linden, J. \& Johnson, RG. (1993). Molecular cloning and characterization of the human A3 adenosine receptor. Proceedings of the National Academy of Sciences of the United States of America, Vol. 90, No. 21, (November, 1993), pp. (10365-10369).

Sawynok, J. (1998). Adenosine receptor activation and nociception. European Journal of Pharmacology, Vol. 347, No. 1, (April, 1998), pp. (1-11).

Sawynok, J. (2009). Adenosine Receptors, In: Peripheral Receptor Targets for Analgesia: Novel Approaches to Pain Management, Brian E Cairns, pp. (137-152), John Wiley and Sons, Inc, ISBN: 978-0-470-25131-7, New Jersey, USA

Sawynok, J. (2011). Methylxanthines and pain, In: Methylxanthines - Handbook Experimental Pharmacology, Bertil B Fredholm, Vol. 200, pp. (311-329), Springer Berlin Heidelberg, ISBN: 3642-134424, Berlin, Germany

Sawynok, J. \& Liu, XJ. (2003). Adenosine in the spinal cord and periphery: release and regulation of pain. Progress in Neurobiology, Vol. 69, No. 5, (April, 2003), pp. (313-340)

Sawynok, J., Sweeney, MI. \& White, TD. (1989). Adenosine release may mediate spinal analgesia by morphine. Trends in Pharmacological Sciences, Vol. 10, No. 5, (May, 1989), pp. (186-189)

Sawynok, J., Zarrindast, MR., Reid, AR. \& Doak, GJ. (1997). Adenosine A3 receptor activation produces nociceptive behaviour and edema by release of histamine and 5-hydroxytryptamine. European Journal of Pharmacology, Vol. 333, No. 1, (August, 1997), pp. (1-7)

Schneider, L., Pietschmann, M., Hartwig, W., Marcos, SS., Hackert, T., Gebhard, MM., Uhl, W., Büchler, MW. \&Werner, J. (2006). Inosine reduces microcirculatory disturbance and inflammatory organ damage in experimental acute pancreatitis in rats. American Journal of Surgery, Vol. 191, No. 4, (April, 2006), pp. (510-514)

Schulte, G. \& Fredholm, BB. (2003). Signalling from adenosine receptors to mitogen-activated protein kinases. Cell Signalling, Vol 15, No. 9, (September, 2003), pp. (813-827)

Seymour, RA., Hawkesford, JE., Hill, CM., Frame, J. \& Andrews, C. (1999). The efficacy of a novel adenosine agonist (WAG 994) in postoperative dental pain. British Journal of Clinical Pharmacology, Vol. 47, No. 6, (June, 1999), pp. (675-680)

Shneyvays, V., Zinman, T. \& Shainberg, A. (2004). Analysis of calcium responses mediated by the A3 adenosine receptor in cultured newborn rat cardiac myocytes. Cell Calcium, Vol. 36, No. 5, (November, 2004), pp. (387-396)

Sneyd, JR., Langton, JA., Allan, LG., Allan, LG., Peacock, JE. \& Rowbotham, DJ. (2007). Multicenter evaluation of the adenosine agonist GR79236X in patients with dental pain after third molar extraction. British Journal of Anaesthesia, Vol. 98, No. 5, (May, 2007), pp. (672 -676)

Sollevi, A., Belfrage, M., Lundeberg, T., Segerdahl, M. \& Hansen, P. (1995). Systemic adenosine infusion: a new treatment modality to alleviate neuropathic pain. Pain, Vol. 61, No. 1, (April, 1995), pp. (155-158) 
The Involvement of Purinergic System in Pain:

Adenosine Receptors and Inosine as Pharmacological Tools in Future Treatments

Song, JG., Hahm, KD., Kim, YK., Leem, JG., Lee, C., Jeong, SM., Park, PH. \& Shin, JW. (2011). Adenosine triphosphate-sensitive potassium channel blockers attenuate the antiallodynic effect of R-PIA in neuropathic rats. Anesthesia $\mathcal{E}$ Analgesia, Vol. 112, No. 6, (June, 2011), pp. (1494-1499)

Sowa, NA., Taylor-Blake, B. \& Zylka, MJ. (2010a). Ecto-5'-nucleotidase (CD73) inhibits nociception by hydrolyzing AMP to adenosine in nociceptive circuits. The Journal of Neurosci, Vol. 30, No. 6, (February, 2010), pp. (2235-2244), ISSN: 1529-2401

Sowa, NA., Voss, MK. \& Zylka, MJ. (2010b). Recombinant ecto-5'-nucleotidase (CD73) has long lasting antinociceptive effects that are dependent on adenosine A1 receptor activation. Molecular Pain, Vol. 6, No. 20, (April, 2010)

Suzuki, R., Stanfa, LC., Kowaluk, EA., Williams, M., Jarvis, MF. \& Dickenson, AH. (2001). The effect of ABT-702, a novel adenosine kinase inhibitor, on the responses of spinal neurones following carrageenan inflammation and peripheral nerve injury. British Journal of Pharmacology, Vol. 132, No. 7, (April, 2001), pp. (1615-1623).

Sweeney, MI., White, TD., Jhamandas, KH. \& Sawynok, J. (1987b). Morphine releases endogenous adenosine from the spinal cord in vivo. European Journal of Pharmacology, Vol. 141, No. 1, (September, 1987), pp.(169-170)

Sweeney, MI., White, TD. \& Sawynok, J. (1987a). Involvement of adenosine in the spinal antinociceptive effects of morphine and noradrenaline. The Journal of Pharmacology and Experimental Therapeutics, Vol. 243, No. 2, (November, 1987) pp. (657-665)

Sweeney, MI., White, TD. \& Sawynok, J. (1989). Morphine, capsaicin and K+ release purines from capsaicin-sensitive primary afferent nerve terminals in the spinal cord. The Journal of Pharmacology and Experimental Therapeutics, Vol. 248, No. 1, (January, 1989), pp. (447-454)

Taiwo, YO. \& Levine, JD. (1990). Direct cutaneous hyperalgesia induced by adenosine. Neuroscience, Vol. 38, No. 3, (March, 1990), pp. (757-762)

Udelson, JE., Heller, GV., Wackers, FJ., Chai, A., Hinchman, D., Coleman, PS., Dilsizian, V., DiCarli, M., Hachamovitch, R., Johnson, JR., Barrett, RJ. \& Gibbons, RJ. (2004). Randomized, controlled dose-ranging study of the selective adenosine A2A receptor agonist binodenoson for pharmacological stress as an adjunct to myocardial perfusion imaging. Circulation, Vol. 109, No. 4, (February, 2004), pp. (457-464), ISSN: 1524-4539

Ueda, H. (2006). Molecular mechanisms of neuropathic pain-phenotypic switch and initiation mechanisms. Pharmacology \& Therapeutics, Vol. 109, No. 1-2, (January, 2006), pp. (57-77)

Wagner, H., Milavec-Krizman, M., Gadient, F., Menninger, K., Schoeffter, P., Tapparelli, C., Pfannkuche, HJ. \& Fozard, JR. (1995). General pharmacology of SDZ WAG 994, a potent selective and orally active adenosine A1 receptor agonist. Drug Development Research, Vol. 34, No. 3, (March, 1995), pp. (276 - 288).

Wan, TC., Ge, ZD., Tampo, A., Mio, Y., Bienengraeber, MW., Tracey, WR., Gross, JG., Kwok, WM. \& Auchampach, JA. (2008). The A3 adenosine receptor agonist CP-532,903 [N6-(2,5-dichlorobenzyl)-3'-aminoadenosine-5'-N-methylcarboxamide] protects against myocardial ischemia/reperfusion injury via the sarcolemmal ATPsensitive potassium channel. The Journal of Pharmacology and Experimental Therapeutics, Vol. 324, No. 1, (September, 2007), pp. (234-243), ISSN: 1521-0103 
Wu, WP., Hao, JX., Halldner, L., Lövdahl, C., DeLander, GE., Wiesenfeld-Hallin, Z., Fredholm, BB. \& Xu, XJ. (2005). Increased nociceptive response in mice lacking the adenosine A1 receptor. Pain, Vol. 113, No. 3, (February, 2005), pp. (395-404).

Wu, MM., You, SW., Hou, B., Jiao, XY., Li, YY. \& Ju, G. (2003). Effects of inosine on axonal regeneration of axotomized retinal ganglion cells in adult rats. Neuroscience Letters, Vol. 341, No. 1, (April, 2003), pp. (84-86).

Wu, WP., Hao, JX., Halldner-Henriksson, L., Xu, XJ., Jacobson, MA., Wiesenfeld-Hallin, Z. \& Fredholm, BB. (2002). Decreased inflammatory pain due to reduced carrageenaninduced inflammation in mice lacking adenosine A3 receptors. Neuroscience, Vol. 114, No. 3, (October, 2002), pp. (523-527)

Yan, L., Burbiel, JC., Maass, A. \& Muller, CE. (2003). Adenosine receptor agonists from basic medicinal chemistry to clinical development. Expert Opinion on Emerging Drugs, Vol. 8, No. 2, (November, 2003), pp. (537 -576), ISSN: 1472-8214

Yoon, MH., Bae, HB. \& Choi, JI. (2005). Antinociception of intrathecal adenosine receptor subtype agonists in rat formalin test. Anesthesia \& Analgesia, Vol. 101, No. 5, (November, 2005), pp. (1417-1421), ISSN: 1526-7598

Zahn, PK., Straub, H., Wenk, M. \& Pogatzki-Zahn, EM. (2007). Adenosine A1 but not A2a receptor agonist reduces hyperalgesia caused by a surgical incision in rats: a pertussis toxin-sensitive G protein-dependent process. Anesthesiology, Vol. 107, No. 5, (November, 2007), pp. (797-806)

Zhang, Y., Li, A., Lao, L., Xin, J., Ren, K., Berman, BM. \& Zhang, RX. (2011). Rostral ventromedial medulla $\mathrm{mu}$, but not kappa, opioid receptors are involved in electroacupuncture anti-hyperalgesia in an inflammatory pain rat model. Brain Research, Vol. 1395, (June, 2011), pp. (38-45)

Zylka, MJ. (2010). Needling adenosine receptors for pain relief. Nature Neuroscience, Vol. 13, No. 7, (July, 2010), pp. (783-784), ISSN: 1546-1726

Zylka, MJ. (2011). Pain-relieving prospects for adenosine receptors and ectonucleotidases. Trends in Molecular Medicine, Vol. 17, No. 4, (April, 2011), pp. (188-196) 


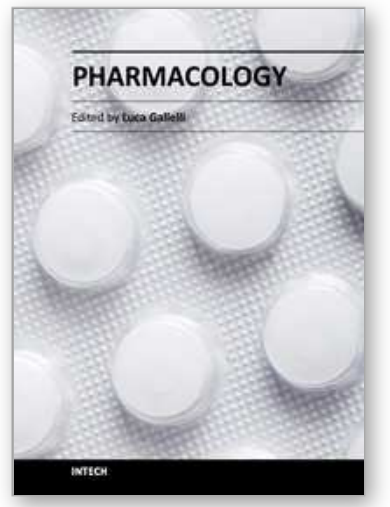

\author{
Pharmacology \\ Edited by Dr. Luca Gallelli
}

ISBN 978-953-51-0222-9

Hard cover, 720 pages

Publisher InTech

Published online 14, March, 2012

Published in print edition March, 2012

The history of pharmacology travels together to history of scientific method and the latest frontiers of pharmacology open a new world in the search of drugs. New technologies and continuing progress in the field of pharmacology has also changed radically the way of designing a new drug. In fact, modern drug discovery is based on deep knowledge of the disease and of both cellular and molecular mechanisms involved in its development. The purpose of this book was to give a new idea from the beginning of the pharmacology, starting from pharmacodynamic and reaching the new field of pharmacogenetic and ethnopharmacology.

\title{
How to reference
}

In order to correctly reference this scholarly work, feel free to copy and paste the following:

Francisney Pinto Nascimento, Sérgio José Macedo Jr. and Adair Roberto Soares Santos (2012). The Involvement of Purinergic System in Pain: Adenosine Receptors and Inosine as Pharmacological Tools in Future Treatments, Pharmacology, Dr. Luca Gallelli (Ed.), ISBN: 978-953-51-0222-9, InTech, Available from: http://www.intechopen.com/books/pharmacology/the-involvement-of-the-purinergic-system-in-pain-adenosinereceptors-and-inosine-as-pharmacological-

\section{INTECH}

open science | open minds

\section{InTech Europe}

University Campus STeP Ri Slavka Krautzeka 83/A 51000 Rijeka, Croatia Phone: +385 (51) 770447

Fax: +385 (51) 686166 www.intechopen.com

\section{InTech China}

Unit 405, Office Block, Hotel Equatorial Shanghai No.65, Yan An Road (West), Shanghai, 200040, China 中国上海市延安西路65号上海国际贵都大饭店办公楼405单元 Phone: +86-21-62489820

Fax: +86-21-62489821 
(C) 2012 The Author(s). Licensee IntechOpen. This is an open access article distributed under the terms of the Creative Commons Attribution 3.0 License, which permits unrestricted use, distribution, and reproduction in any medium, provided the original work is properly cited. 